\title{
Operationalized psychodynamic diagnosis: a systematic review of the literature
}

\author{
Diagnóstico psicodinâmico operacionalizado: uma revisão sistemática \\ da literatura
}

Luciane Maria Both, ${ }^{1}$ (D) André Goettems Bastos, ${ }^{2}$ Lúcia Helena Machado Freitas ${ }^{1}$

\begin{abstract}
Introduction: The Operationalized Psychodynamic Diagnosis (OPD-2) is an operational multiaxial diagnostic assessment and treatment planning tool. This systematic review sought to analyze empirical studies that used the OPD as an instrument. In addition to identifying the studies, we analyzed the topics covered and the results of research that used the OPD empirically.

Method: Articles, dissertations and empirical theses that mentioned or used the OPD instrument in the last five years (2012-2017) were included in this review. The strategy included searching with combinations of the descriptors "Operationalized and psychodynamic and diagnosis" from the Portal de Periódicos CAPES on the PubMed, Google Scholar, and ResearchGate databases for work published in English, Portuguese or Spanish in the last five years.

Results: The search returned a total of 189 papers, but only 20 were included. The studies selected discussed the validity and reliability of the instrument, the therapeutic process and analysis of outcomes, assessment of different mental disorders, and also included studies comparing different instruments and techniques. Considerable scientific effort has evidently been dedicated to accumulating more consistent data on psychodynamic diagnosis. Conclusion: It was demonstrated that the OPD is an essential clinical tool for dimensional comprehension of the subject and for scientific research. However, the number of publications on the subject is not yet significant and the methods employed are diverse. Nevertheless, there is a growing body of data on topics such as applicability in different contexts and to different pathologies, promoting greater visibility and with greater representativeness of professionals who have experience with the instrument.
\end{abstract}

Keywords: Diagnosis, assessment, psychodynamics, review.

\section{Resumo}

Introdução: O Diagnóstico Psicodinâmico Operacional (OPD-2) é uma ferramenta operacional de avaliação diagnóstica multiaxial e planejamento terapêutico. Esta revisão sistemática buscou analisar estudos empíricos que utilizassem o OPD como instrumento; além de identificar os estudos, foram verificados os tópicos e resultados de pesquisa que utilizaram empiricamente o OPD.

Método: Foram incluídos os artigos, dissertações e teses empíricas dos últimos cinco anos (2012 a 2017) que abordaram ou utilizaram o instrumento OPD. A estratégia de busca incluiu o cruzamento dos descritores "Operacionalizado e Psicodinâmico e Diagnóstico", do Portal de Periódicos CAPES, nas bases de dados do PubMed, Google Scholar, ResearchGate, publicado em inglês, português ou espanhol nos últimos cinco anos.

Resultados: A busca resultou em um total de 189 artigos, mas apenas 20 foram incluídos. Os estudos selecionados trataram da validade e confiabilidade do instrumento, processo terapêutico e análise de resultados, avaliação de diferentes transtornos mentais e estudos comparativos com diferentes instrumentos ou técnicas. Um notável esforço científico no desenvolvimento de dados mais consistentes sobre o diagnóstico psicodinâmico.

Conclusão: Demonstrou-se que a OPD é uma ferramenta clínica essencial em relação à compreensão dimensional do sujeito e em pesquisas científicas. No entanto, o número de produções sobre o assunto ainda não é significativo, os métodos são diversos, mas os dados estão crescendo, como: a aplicabilidade em diferentes contextos, diferentes patologias, promover maior visibilidade com maior representatividade de profissionais que possuem conhecimento do instrumento.

Descritores: Diagnóstico, avaliação, psicodinâmica, revisão.

\footnotetext{
${ }^{1}$ Universidade Federal do Rio Grande do Sul (UFRGS), Porto Alegre, RS, Brazil. ${ }^{2}$ Pontifícia Universidade Católica do Rio Grande do Sul (PUCRS), Porto Alegre, Brazil. 


\section{Introduction}

An instrument called the Operationalized Psychodynamic Diagnosis was created in Germany in 1992 (Operationalisierte Psychodynamische Diagnostik, OPD), integrating the psychodynamic dimension with descriptive symptomatology. One of the reasons for creating the OPD was the existence of limitations affecting previous diagnostic classifications such as the current Diagnostic and Statistical Manual of Mental Disorders (DSM-5) and the International Classification of Diseases and Related Health Problems (ICD-10), which employ symptom-centered diagnosis. The current version of the operationalized manual is the 2 nd edition and it has been validated in the following languages: German, Spanish, Portuguese (Portugal and Brazil), ${ }^{1-3}$ and English.

The OPD-2 is a multiaxial diagnostic system comprising five axes; the first four focused on psychodynamic understanding and the last one on description, as follows: I) experience of illness and prerequisites for treatment; II) interpersonal relationships; III) psychic conflict; IV) psychic structure; V) traditional nosological diagnosis, such as DSM-5 and ICD-10. Each axis has specific assessment categories, as shown in Table 1 . The objective of the OPD-2 is a psychodynamic formulation, describing the patient's main problems and identifying their resources and skills. More specifically, the OPD complements the descriptive indicators of the DSM and ICD from

Table 1 - Description of the axes of the Operationalized Psychodynamic Diagnosis (OPD-2)

\begin{tabular}{|c|c|c|}
\hline Axes & Dimension & Indicator \\
\hline \multirow[t]{4}{*}{$\begin{array}{l}\text { Axis I - Illness experience and } \\
\text { prerequisites for treatment }\end{array}$} & Objective assessment of illness/problem & $\begin{array}{l}\text { 1.Current severity of illness/ problem } \\
\text { 2. Period of illness/problem }\end{array}$ \\
\hline & $\begin{array}{l}\text { Patient experience, presentation and } \\
\text { conceptualization of the illness }\end{array}$ & $\begin{array}{l}\text { 3. Experience and presentation of the disease } \\
\text { 4. Conceptualization of the illness by the patient } \\
\text { 5. Conceptualization of change by the patient }\end{array}$ \\
\hline & \multirow[t]{2}{*}{ Resources and resistance to change } & 6. Resources for change \\
\hline & & 7. Resistances to change \\
\hline \multirow[t]{2}{*}{$\begin{array}{l}\text { Axis II - Interpersonal } \\
\text { relations }\end{array}$} & Perspective A: Patient experience & $\begin{array}{l}\text { The patient perceives himself as... } \\
\text { The patient perceives others as... }\end{array}$ \\
\hline & $\begin{array}{l}\text { Perspective B: The perception of others (including } \\
\text { of the researcher) }\end{array}$ & Others perceive the patient as... \\
\hline \multirow{11}{*}{ Axis III - Conflict } & \multirow[t]{7}{*}{ Repetitive dysfunctional conflicts } & 1. Individuation versus dependency \\
\hline & & 2. Submission versus control \\
\hline & & 3. The need for care versus self-sufficiency \\
\hline & & 4. Conflict of self-esteem \\
\hline & & 5. Conflict of guilt \\
\hline & & 6. Oedipal conflict \\
\hline & & 7. Identity conflict \\
\hline & \multirow[t]{4}{*}{ How the main conflict is handled } & Predominantly active \\
\hline & & Mixed more active \\
\hline & & Mixed more passive \\
\hline & & Predominantly passive \\
\hline \multirow[t]{8}{*}{ Axis IV - Structure } & \multirow[t]{2}{*}{ Cognitive abilities } & 1a. Self-perception \\
\hline & & 1b. Perception of the object \\
\hline & \multirow[t]{2}{*}{ Regulation } & 2a. Self-regulation \\
\hline & & 2b. Regulation of the object relation \\
\hline & \multirow[t]{2}{*}{ Emotional communication } & 3a. Internal communication \\
\hline & & 3b. Communication with the outside world \\
\hline & \multirow[t]{2}{*}{ Attachment } & 4a. Internal objects \\
\hline & & 4b. External objects \\
\hline \multirow{2}{*}{$\begin{array}{l}\text { Axis V - Mental and } \\
\text { psychosomatic disorders }\end{array}$} & Mental disorders & Main/additional diagnostics \\
\hline & Personality disorders & Main/additional diagnostics \\
\hline
\end{tabular}

Adapted from Vicente et al. ${ }^{3}$ 
a psychodynamic point of view, proposing therapeutic foci and treatment plans tailored to each patient, linking a cross-sectional diagnostic evaluation (five diagnostic axes) with a longitudinal evaluation (assessment of the process of change in each axis with treatment planning) and supporting a diagnostic and therapeutic classification of change in empirical investigations with a psychoanalytic focus. ${ }^{1-6}$

The OPD-2 is considered one of the main instruments for clinical diagnosis, planning, and scientific research in the international context. It's also used for training future psychotherapists. ${ }^{3}$ It is a rigorous and standardized psychodynamic diagnostic method with specific assessment criteria to facilitate communication in the scientific community and for applying research to clinical practice. ${ }^{5}$ In Germany and Switzerland, the OPD-2 is considered an essential resource for certifying the quality of interventions, both in the hospital setting and in the traditional clinic, to assess the evolution and progress of treatment, and from this point on provide a new plan and psychodynamic understanding of the patient. ${ }^{3}$ This diagnostic tool enables assessment, both quantitatively and qualitatively, of change variables (symptoms, relational patterns, conflicts, and structure), efficacy, and the therapeutic relationship in an operationalized form, and also adjustment of treatment planning; it therefore enables process and outcome research.

Considering the important contribution made by the OPD, from the perspectives of both diagnostic assessment and of psychotherapeutic planning, and also to operationalization of psychodynamic concepts, this systematic review sought to analyze empirical studies that used the OPD as an instrument. Therefore, in addition to identifying the studies, we also analyzed the topics covered and the results of research that used OPD empirically.

\section{Method}

A systematic review of the scientific production was carried out according to PRISMA Platform guidelines. The strategy involved searching for combinations of the descriptors "Operationalized and psychodynamic and diagnosis" from Portal de Periódicos CAPES on PubMed, Google Scholar, and ResearchGate as well as in unpublished studies identified by direct contact with researchers in the area. The search for articles was performed in January 2018.

Articles, dissertations and empirical theses that mentioned or used the OPD instrument in the last five years (2012-2017) were included in this review.
Theoretical articles, duplicated articles, articles in languages other than English, Portuguese or Spanish, and articles without access to the complete document were excluded from this review.

We sought to control for possible selection biases by searching the databases at two different times using the same descriptors. Also, authors on the subject were contacted about possible unpublished articles to include in this review; however, we are cannot be sure to have contacted all authors, because of the vast number of researchers on the matter. Another issue is the exclusion of articles in foreign languages such as German and French, which could possibly have enriched the discussion in this review. In relation to assessment of articles included, each article was analyzed separately, seeking to understand how the OPD was used in each study. One important limitation is the fact that the researchers are not specialized in the neurobiological aspects that some articles elaborate further on; in this sense, some aspects have been described superficially.

\section{Results}

Selection of studies from among the 189 identified by searches took place in two stages: 1st screening, reading of abstracts only; 2nd screening, a complete reading of the study. Thus, 166 studies were excluded, and then four unpublished studies were included in the databases. Hence, a total of 20 studies were analyzed (Figure 1 ).

Table 2 shows all the articles analyzed. The central theme addressed in relation to the OPD instrument varied. There were articles on psychometric validation of the instrument $(n=2)$, studies in different contexts and with a variety of psychopathologies - PTSD, depression, personality disorder, eating disorder, conduct disorder - $(n=13)$, and comparative studies or studies proposing new techniques $(n=5)$. In regards to the locations where research was conducted, it was found that Chile $(n=6)$, Germany $(n=5)$ and Brazil ( $n$ $=3$ ) lead in empirical research with the OPD, although one Brazilian publication is still in the editorial process, with submission approved; followed by Italy $(n=1)$, Portugal ( $n=1)$, Argentina $(n=1)$, the United States $(n=1)$, and Australia $(n=1)$. It should be considered that these data would be different if articles in German had not been excluded. The periods in which the greatest numbers of articles were published were from 2012 to 2014 and 2017. It is evident that investigation of the operationalized psychodynamic diagnosis is a fertile field for research development. 
189 articles identified in databases

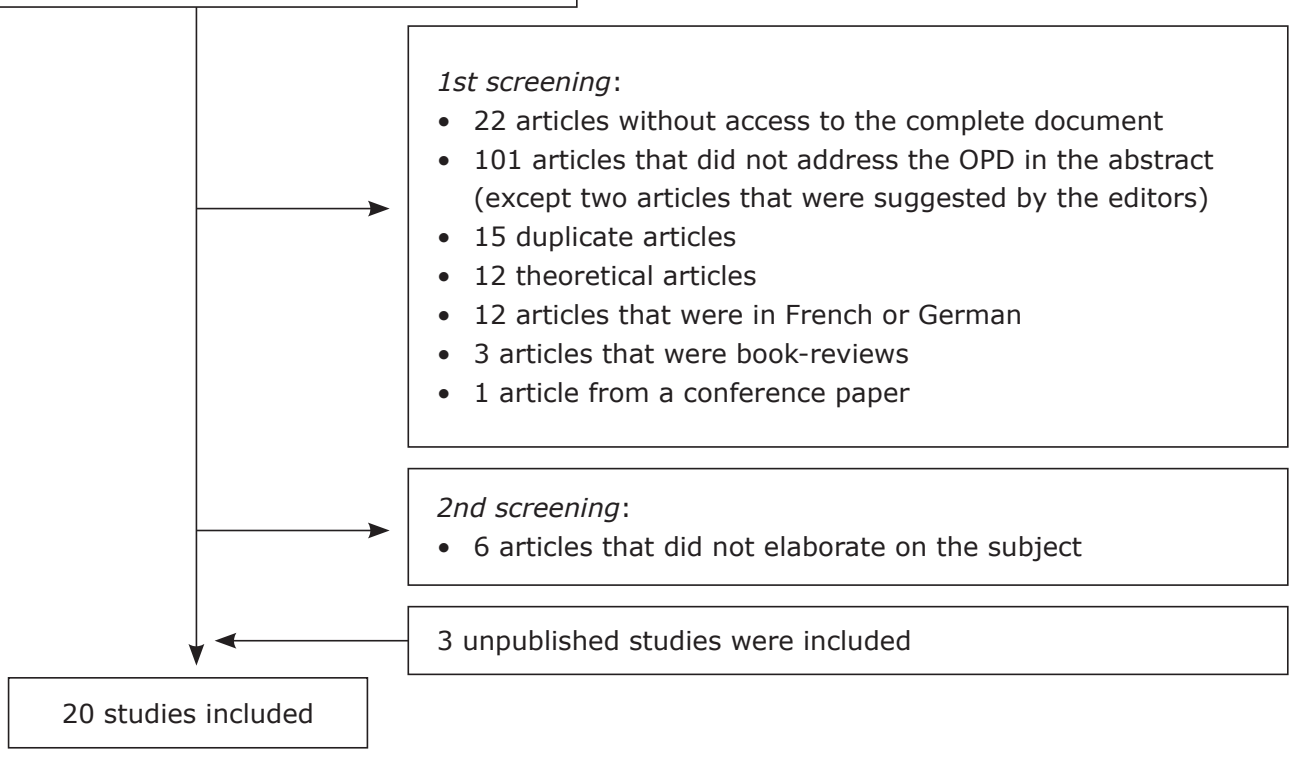

Figure 1 - Selection of articles included in and excluded from the systematic review.

Table 2 - Description of the selected articles

\begin{tabular}{|c|c|c|c|c|}
\hline Article & Objective & Method & Results & Conclusion \\
\hline Alvarado ${ }^{7}$ & $\begin{array}{l}\text { To identify the } \\
\text { psychodynamic and cognitive } \\
\text { factors associated with } \\
\text { adherence to medical } \\
\text { treatment in non-refractory } \\
\text { epileptic outpatients. }\end{array}$ & $\begin{array}{l}\text { Non-experimental, comparative } \\
\text { and cross-sectional study. } \\
33 \text { Chilean epilepsy patients ( } 23 \\
\text { adherents, } 10 \text { non-adherents). } \\
\text { Instruments: Morisky Medication } \\
\text { Assessment Scale-4, OPD-2. }\end{array}$ & $\begin{array}{l}\text { Adherent patients were: younger; } \\
\text { had higher education; had higher GAF } \\
\text { scores, suggesting better psychosocial } \\
\text { adjustment; and lower scores on the } \\
\text { EQ-5D; they express their disorder } \\
\text { mainly psychologically, while non- } \\
\text { adherent patients tend to express } \\
\text { themselves in somatic ways. } \\
\text { The main conflict for both groups was } \\
\text { "Need for care versus self-sufficiency". }\end{array}$ & $\begin{array}{l}\text { Adherence to treatment has } \\
\text { become an issue on its own. } \\
\text { There are seven variables } \\
\text { associated with adherence to } \\
\text { medical treatment: years of } \\
\text { education attained, psychosocial } \\
\text { adjustment, health-related } \\
\text { quality of life, psychological and } \\
\text { social concept of illness, desired } \\
\text { psychological treatment, and } \\
\text { submission/control conflict. }\end{array}$ \\
\hline Both ${ }^{8}$ & $\begin{array}{l}\text { To identify psychodynamic } \\
\text { characteristics from an } \\
\text { audio-recorded treatment } \\
\text { session with an } 18 \text {-year-old } \\
\text { teenager in conflict with } \\
\text { the law, serving detention } \\
\text { Without the Possibility of } \\
\text { External Activities. }\end{array}$ & $\begin{array}{l}\text { Systematic case of an } 18 \text {-year- } \\
\text { old. } \\
\text { Fonagy Mentalization-Based } \\
\text { Treatment. } \\
\text { Instrument: OPD-2. } \\
\text { Analysis of a } 45 \text {-minute session. }\end{array}$ & $\begin{array}{l}\text { Median problem severity, but with } \\
\text { almost no suffering. } \\
\text { Experiences others as controllers, } \\
\text { who disqualify and neglect him, thus, } \\
\text { keeps to himself by maintaining } \\
\text { distance; there are uncontrolled } \\
\text { impulses and exposures to risk. } \\
\text { Conflict: "need for care versus self- } \\
\text { sufficiency". } \\
\text { Median structure level. } \\
\text { ICD F91. }\end{array}$ & $\begin{array}{l}\text { It was possible to develop a } \\
\text { dimensional understanding of } \\
\text { the adolescent, to complement } \\
\text { the nosological diagnosis, from } \\
\text { the OPD-2. The instrument } \\
\text { was useful in assessment } \\
\text { and treatment planning of } \\
\text { adolescents in conflict with the } \\
\text { law. }\end{array}$ \\
\hline Both $^{9}$ & $\begin{array}{l}\text { To assess the psychodynamic } \\
\text { functioning of patients with } \\
\text { stress disorder through } \\
\text { OPD-2, regarding the } \\
\text { structure, intrapsychic } \\
\text { conflict, and interactional } \\
\text { pattern of the subject. }\end{array}$ & $\begin{array}{l}\text { Cross-sectional quantitative } \\
\text { study. } \\
\text { Three patients with PTSD or } \\
\text { ASD symptoms, selected by } \\
\text { convenience. } \\
\text { Instrument: OPD-2. } \\
\text { Test-retest reliability. }\end{array}$ & $\begin{array}{l}\text { Moderate level of subjective suffering, } \\
\text { with limitations in daily activities. } \\
\text { Excessive self-care and constant state } \\
\text { of alert. Remains distant from others. } \\
\text { Conflict: "need for care versus self- } \\
\text { sufficiency". } \\
\text { Median structure level. } \\
\text { ASD or PTSD. }\end{array}$ & $\begin{array}{l}\text { OPD provided an understanding } \\
\text { of the patients' psychodynamic } \\
\text { functioning in a clearer } \\
\text { form that may facilitate the } \\
\text { understanding of the clinical } \\
\text { context of stress. }\end{array}$ \\
\hline Crempien $^{6}$ & $\begin{array}{l}\text { To characterize a Chilean } \\
\text { sample of victims of } \\
\text { domestic violence through } \\
\text { an operationalized } \\
\text { psychodynamic diagnosis, } \\
\text { exploring structural } \\
\text { functions, interpersonal } \\
\text { dysfunctions and intrapsychic } \\
\text { conflicts. }\end{array}$ & $\begin{array}{l}\text { Non-experimental, correlational } \\
\text { and cross-sectional study } \\
\text { Instrument: OPD. } \\
28 \text { women from a care center } \\
\text { for domestic violence victims in } \\
\text { Santiago. }\end{array}$ & $\begin{array}{l}\text { Women with greater severity of } \\
\text { violence reported higher levels of } \\
\text { depressive symptoms, PTSD and low } \\
\text { education. } \\
\text { Conflict: "need for care versus self- } \\
\text { sufficiency". } \\
\text { Vulnerable structure level. }\end{array}$ & $\begin{array}{l}\text { Understanding of the } \\
\text { psychological difficulties and } \\
\text { vulnerable relationships of the } \\
\text { victims associated with their } \\
\text { traumatic experiences promotes } \\
\text { more systematized care that } \\
\text { prevents the re-victimization, } \\
\text { based on the therapeutic focus } \\
\text { and planning. }\end{array}$ \\
\hline
\end{tabular}


Table 2 (cont.)

\begin{tabular}{lll}
\hline Article & Objective & Method \\
\hline Crempien $^{10}$ & To analyze the effects of & Cross-sectional, correlational \\
& personality functioning & study. 84 outpatients from \\
& on the quality of life in & Santiago, mean age 45 years, \\
depressed patients. & 89.3\% women. \\
& Instruments: BDI, OPD-SQ and \\
& SF-36.
\end{tabular}

Results
High level depressive severity
symptoms are associated with low
levels of personality functioning and
poor quality of life. Sociodemographic
variables showed no effect on quality
of life.

Conclusion

Depressive symptoms mediate

the effect of personality

the effect of personality
functioning on mental quality of

life of depressive patients. The

lower the level of personality

functioning, the higher

the severity of depressive

symptoms, and the latter

have a detrimental effect on patients' quality of life. The specific contribution of each structural function to this impairment should be further studied.

Dagnino ${ }^{11} \quad$ To describe the therapeutic process of four successful therapies, considering the change with reference to the subjective theory and integration of therapeutic foci and to compare and relate the two methods

for assessing therapeutic change.

Dagnino ${ }^{12} \quad$ To determine the presence of therapeutic foci, their level of integration and their relationship with subjective change in four successful brief dynamic psychotherapies.

Dagnino $^{13} \quad$ To explore the association between structural functions and self-criticism and dependency dimensions of depressive experience.

Dinger ${ }^{14} \quad$ To investigate the OPD classification of levels of personality functioning from different perspectives. To investigate the predictive value of classification of interviews for PD according to the DSM-IV.

Doering ${ }^{15} \quad$ To evaluate the reliability and validity of the OPD-2 structure axis in 124 structure axis in 124
psychiatric patients.

Gordon \& Stoffey ${ }^{16}$

To evaluate the stability and validity of the PDC as an operationalization of the PDM.

To use the OPD- 2 criteria for a secondary analysis of 15 psychoanalytic interviews conducted previously, using the multiaxial diagnostic classification.

Kehyayan ${ }^{17} \quad$ To investigate the concept of "psychodynamic conflict" using a method of free association to potentially conflict-related contents inside a functional MRI scanner. subjects, 43

Instruments: MMPI-2;

Karolinska Psychodynamic Profile; Axis IV from OPD.
4 women with individual brief dynamic psychotherapy sessions, therapists with over 30 years of experience. Structural Change, OPD-2.

Study of multiple unique cases. 4 brief dynamic psychotherapies.

Instruments: Generic Change Indicators, OPD-2, Heidelberg Structural Change Scale, Foci Presence Scale, Outcome Questionnaire.

Cross-sectional, non43 Chilean depressive patients (83.7\% women) Instruments: BDI, Depressive Experiences Questionnaire, OPD-SQ

79 clinical and 22 non-clinical depressive patients. Mean age 32 years, $70 \%$ women, $53 \%$ with comorbidity (PD)

Measurements: OPD-LSIA corresponding to Axis IV from the Clinical Interview of the OPD. And OPD-SQ.

124 psychiatric patients. Instruments: Structured Clinica Interview for DSM-IV, OPD-2. Instruments: Generic Indicators of Therapeutic Change, Scale of of the therapeutic foci. There is a models of assessing therapeutic Vulnerability in the self-regulation structure) and axis II in the patient's prognostic inferences and a conceptualization of the case of a patient with GAD. Instrument: OPD-2.

18 participants, 10 women mean age of 25.9 years. Instruments: OPD - conflict sentences -, SCL-90, BDI and DSQ-40.

24 stimulus sentences: 6 were "neutral", 6 were "negative", 12 were "conflict-related". with high levels of behavioral, neural

cingulate cortex, involving emotional

processing, monitoring of conflict and

the problems mentioned.
The change, in subjective theory, proved to be an irregular but progressive process, with integration significant relationship between the change.

The focus of OPD was identified in all the occurrences of therapeutic change. The focus on the relational pattern is more present in early stages, while the focus on structura vulnerabilities predominates in the final stage.

More severe depressive symptomatology, especially in the self-criticism dimension, is associated with worse structural functioning. function was a predictor of depressive symptomatology.

OPD-SQ correlated significantly with OPD-LSIA.

The non-clinical classification was significantly lower than the depressive patients.

OPD-SQ and OPD-LSIA were

predictors for DSM-IV PDs.

The OPD-2 structure axis shows good interrater reliability. Patients with a PD showed significantly worse personality functioning than those without. In cluster B PD, personality functioning was more severely impaired than in cluster C PD.

The PDC contains the Overal Personality Organization Scale with 7 subscales and the Mental Functioning Scale with 9 subscales. Both were negatively correlated with MMPI-2, OPD, and the DSM-IV GAF scale $(p<0.001)$.

Preliminary results indicated that axes III and IV predominated in identifying the problem (conflict $x$ expectations regarding treatment.

It is suggested that foci should be identified in each episode of change that the patient and the therapist are working on, in order to establish a relationship between a specific focus, its level of integration and the subjective change in the patient.

The consistency of successful psychotherapeutic processes allowed conclusions on certain common aspects of focalizations, their level of integration and their evolution during the process. The focus was the need to abbreviate the therapeutic processes.

The foundation of depression s heterogeneous, requiring different therapeutic strategies.

\author{
(n)
}

There is agreement between OPD- LSIA and OPD-SQ regarding the assessment of personality functioning.

The OPD-2 structure axis shows good reliability as well as concurrent and discriminant validity and can be recommended for clinical use and research purposes.

PDC scales had high internal consistency, reliability and validity. The PDC can be used for diagnosis, treatment, psychodynamic formulation, outcome and process research based on PDM.

OPD-2 was useful in classifying key elements of the conceptualization process of a GAD case and was sensitive to identify patient's particularities.

There was agreement between the report of conflict-related sentences, reactions, mainly in the anterior

Free association has shown to be a powerful technique for investigating conflict with neuroimaging. 
Table 2 (cont.)

\begin{tabular}{|c|c|c|c|c|}
\hline Article & Objective & Method & Results & Conclusion \\
\hline Kessler $^{18}$ & $\begin{array}{l}\text { Operationalizing repression } \\
\text { using individualized } \\
\text { experimental conditions, } \\
\text { observing behavioral } \\
\text { potential (memory } \\
\text { and reaction time) and } \\
\text { psychophysiological } \\
\text { correlates (skin conductance } \\
\text { response). }\end{array}$ & $\begin{array}{l}29 \text { healthy women were invited } \\
\text { to associate to cue sentences. } \\
\text { Instrument: OPD. }\end{array}$ & $\begin{array}{l}\text { The OPD interview enabled } \\
\text { identification of the psychodynamic } \\
\text { conflicts. Associations to conflict- } \\
\text { related sentences were associated } \\
\text { with longer reaction times and } \\
\text { increased skin conductance } \\
\text { responses. }\end{array}$ & $\begin{array}{l}\text { The results were interpreted } \\
\text { as possible correlates of } \\
\text { repression. It is suggested that } \\
\text { this experimental paradigm may } \\
\text { serve to investigate repression } \\
\text { in clinical populations. }\end{array}$ \\
\hline Krieger $^{2}$ & $\begin{array}{l}\text { To present the Brazilian } \\
\text { version of the OPD- } 2 \text { and } \\
\text { conduct initial studies of } \\
\text { content validity, concurrent } \\
\text { validity and inter-rater } \\
\text { reliability with the Brazilian } \\
\text { version of the OPD- } 2 \text {. }\end{array}$ & $\begin{array}{l}\text { Content assessment. } \\
\text { Reliability: inter-rater } \\
\text { agreement and test-retest of } \\
53 \text { interviews of psychodynamic } \\
\text { psychotherapy. } \\
\text { Concurrent validity: compared } \\
\text { OPD-2 items to the results of } \\
\text { WHOQOL-bref and SCL-90-R. }\end{array}$ & $\begin{array}{l}\text { The Brazilian OPD was created by } \\
\text { adapting the Portuguese version. } \\
\text { The content assessment considered } \\
\text { the items clear in terms of language } \\
\text { and theoretically pertinent. Axes } \\
\text { III and IV showed greater inter- } \\
\text { rater agreement. Axes I, III and IV } \\
\text { obtained a significant correlation in } \\
\text { some categories with the results of } \\
\text { SCL-90-R and WHOQOL-bref. }\end{array}$ & $\begin{array}{l}\text { The psychometric properties } \\
\text { of the OPD- } 2 \text { are adequate } \\
\text { for application to the Brazilian } \\
\text { population. }\end{array}$ \\
\hline Paulo \& Pires ${ }^{5}$ & $\begin{array}{l}\text { To test diagnostic } \\
\text { assessment using the } \\
\text { notes from a patient's } \\
\text { psychoanalysis sessions. }\end{array}$ & $\begin{array}{l}\text { One patient, } 40 \text { years old, with } \\
\text { higher education. } \\
\text { Descriptive notes from } \\
\text { psychoanalysis sessions. } \\
\text { Treatment period: } 3 \text { years and } 8 \\
\text { months with frequency of three } \\
\text { times a week. } \\
\text { The first } 10 \text { and the last } 12 \\
\text { sessions were analyzed. }\end{array}$ & $\begin{array}{l}\text { The patient had a lot of counseled } \\
\text { psychological suffering, dysfunctional } \\
\text { relational patterns, oedipal conflict } \\
\text { and structural level that varied } \\
\text { between moderate/high. There was } \\
\text { significant improvement at the end of } \\
\text { treatment on all axes. }\end{array}$ & $\begin{array}{l}\text { OPD can be applied to } \\
\text { descriptive notes of } \\
\text { psychoanalytic sessions. }\end{array}$ \\
\hline Vicente $^{3}$ & $\begin{array}{l}\text { To describe the } \\
\text { methodological aspects of } \\
\text { the process of cross-cultural } \\
\text { adaptation of the OPD-2 to } \\
\text { the Portuguese language } \\
\text { (Portugal and Brazil). } \\
\text { To evaluate inter-rater } \\
\text { agreement for the different } \\
\text { axes of the instrument in the } \\
\text { scoring of clinical interviews. }\end{array}$ & $\begin{array}{l}\text { Independent translation and } \\
\text { comparison of the different } \\
\text { versions of the final version in } \\
\text { Portuguese. } \\
\text { Agreement between three } \\
\text { independent evaluators of two } \\
\text { interviews of five participants } \\
\text { with mean age of } 40 \text { years. }\end{array}$ & $\begin{array}{l}\text { Inter-rater agreement of Axis I was } \\
66 \% \text {, Axis III was } 57.7 \% \text {, and Axis IV } \\
\text { was } 78 \% \text {. Axis II was not evaluated. }\end{array}$ & $\begin{array}{l}\text { Results are similar to other } \\
\text { studies with an acceptable } \\
\text { inter-rater agreement. Further } \\
\text { studies are recommended to } \\
\text { investigate the instrument's } \\
\text { reliability. }\end{array}$ \\
\hline Wiswede ${ }^{19}$ & $\begin{array}{l}\text { To compare the changes } \\
\text { in depressive patients' } \\
\text { brain reactions before } \\
\text { and after eight months } \\
\text { of psychodynamic } \\
\text { psychotherapy. }\end{array}$ & $\begin{array}{l}\text { Experimental study with } \\
18 \text { patients with major } \\
\text { depressive disorder, mean } \\
\text { age of } 39.8 \text { years, not on } \\
\text { medication, who underwent } \\
\text { MRI before (T1) and } 8 \text { months } \\
\text { after (T2) psychodynamic } \\
\text { psychotherapeutic treatment. } \\
\text { A control group of } 17 \text { subjects } \\
\text { who were tested twice without } \\
\text { intervention, mean age of } 38 \\
\text { years. } \\
\text { Instruments: BDI, OPD. }\end{array}$ & $\begin{array}{l}\text { When confronted with the sentences } \\
\text { from the OPD (as stimulus) at T1, the } \\
\text { patients showed greater activation } \\
\text { in the limbic system and in the } \\
\text { subcortical regions compared to the } \\
\text { control group. } \\
\text { At T2, the differences in brain } \\
\text { activities between the control group } \\
\text { and the patients were no longer } \\
\text { significant. The patient group's } \\
\text { depression score improved. }\end{array}$ & $\begin{array}{l}\text { Brain activity of depressive } \\
\text { patients, in the case of } \\
\text { hyperactivity of the limbic } \\
\text { system, normalized after } \\
\text { treatment; changes were } \\
\text { attributed to psychodynamic } \\
\text { psychotherapy. }\end{array}$ \\
\hline Zimmermann ${ }^{20}$ & $\begin{array}{l}\text { To contribute to the } \\
\text { conceptual and empirical } \\
\text { discussion of the Levels of } \\
\text { Personality Functioning Scale } \\
\text { from the perspective of the } \\
\text { OPD system }\end{array}$ & $\begin{array}{l}\text { Review of studies that used OPD- } \\
\text { LSIA to investigate reliability } \\
\text { and validity. A meta-analysis } \\
\text { was conducted of } 8 \text { studies } \\
\text { that assessed the association } \\
\text { between the overall OPD-LSIA } \\
\text { score and PDs. }\end{array}$ & $\begin{array}{l}\text { OPD-LSIA is reliable and valid for the } \\
\text { assessment of personality structure } \\
\text { and has a high association with } \\
\text { classification of PDs (severity). }\end{array}$ & $\begin{array}{l}\text { Highlights implications of OPD- } \\
\text { LSIA for future revisions to the } \\
\text { DSM-5 proposal. }\end{array}$ \\
\hline Zuccarino ${ }^{21}$ & $\begin{array}{l}\text { This ongoing study aimed } \\
\text { to investigate the existence } \\
\text { of psychopathologically } \\
\text { significant dimensions in } \\
\text { a sample of patients with } \\
\text { eating disorders, using the } \\
\text { OPD-2 system. }\end{array}$ & $\begin{array}{l}50 \text { young women with eating } \\
\text { disorders. } \\
\text { Instrument: OPD-2, Eating } \\
\text { Disorder Inventory } 2 \text {. }\end{array}$ & $\begin{array}{l}\text { Most patients were subjectively } \\
\text { experiencing psychological suffering. } \\
\text { The patients tended to perceive others } \\
\text { as reproachful, controlling, belittling, } \\
\text { and neglectful. The predominant } \\
\text { conflict was the need for care versus } \\
\text { self-sufficiency. Most of the sample } \\
\text { showed poorly integrated functioning. }\end{array}$ & $\begin{array}{l}\text { The existence of different } \\
\text { subgroups of patients with } \\
\text { eating disorders differing } \\
\text { from each other in respect to } \\
\text { psychodynamic features. These } \\
\text { data suggest that tailoring } \\
\text { therapeutic approaches to the } \\
\text { patients' individual profiles } \\
\text { could improve outcomes. }\end{array}$ \\
\hline
\end{tabular}

ASD = acute stress disorder; BDI = Beck Depression Inventory; DSM = Diagnostic and Statistical Manual of Mental Disorders; DSQ-40 = Defense Style Questionnaire; EQ-5D = EuroQol-5D; F91 = conduct disorder; GAD = generalized anxiety disorder; GAF = global assessment functioning; ICD-10 = International Classification of Diseases and Related Health Problems; MMPI-2 = Minnesota Multiphasic Personality Inventory-2; MRI = magnetic resonance imaging; OPD-2 = Operationalized Psychodynamic Diagnosis; OPD-LSIA = OPD Levels of Structural Integration Axis; OPD-SQ = OPD Structure Questionnaire; PD = personality disorders; PDC = Psychodiagnostic Chart; PDM = Psychodynamic Diagnostic Manual; PTSD = posttraumatic stress disorder; SCL-90 = Symptom Checklist-90; SF-36 = Medical Outcome Study 36-item Short-Form; WHOQOL-bref = World Health Organization Quality of Life instrument-Abbreviated version. 


\section{Discussion}

In the last five years, the OPD-2 has spread nationally and internationally and has been applied in validity and reliability studies, ${ }^{2,3}$ in empirical studies with process analysis and treatment outcome, in studies assessing different mental disorders, ${ }^{4-6,8-10,13-15,19-21}$ and in comparative studies with different instruments and techniques or proposing new techniques. ${ }^{11,12,16-18}$

Traditionally, the use of the instrument is operationalized from audio recordings of semi-structured interviews. Thus, Paulo \& Pires, investigated the possibility of applying the instrument to psychoanalytic session notes of a patient when the follow-ups had already been completed. It proved possible to validate application of the OPD in this context. This type of assessment offers a more natural study that allows an independent assessment of the therapist, without the need to record the treatment; since recording can cause unnecessary anxiety in the patient and affect the treatment outcome. ${ }^{5}$

It was also demonstrated that the OPD was sensitive for identifying the particularities of the patients and the construction of the conceptualization of the case (hypotheses, maintaining and precipitating influences of the psychological, interpersonal, and conflictual problems). ${ }^{4}$ In the study by Kehyayan et al., it proved possible to use the free association technique to identify unconscious conflict, with concurrent observation of neural behavior, along with psychological behavior; and the usefulness of this technique was confirmed in investigation of axis III. ${ }^{17}$ Observation of the brain during a psychoanalytic treatment is a fertile field of investigation. ${ }^{16,19}$ However, it is also considered a challenge, since it requires operationalization of psychodynamic constructs, and the OPD provides a method for this type of research, developing and proving the effectiveness of this approach.

It was observed that the OPD system has been used to understand the structural functions of the personalities of depressive patients in terms of assessing their mental capacity for emotional regulation, cognitive abilities, internalized objects, and internal and external communication. In one study, it was observed that the structural level of personality function described in the OPD Structure Questionnaire (OPD-SQ) is associated with the quality of life of patients with depressive symptoms; data from the Chilean group study focused on the issue of depression because of its high prevalence in the country. Low levels of personality functioning correlated with high depressive severity and low quality of life. These results suggest a need to understand the detriment to quality of life of patients with depression, especially the most serious, in relation to their overall functioning of personality. ${ }^{10}$ Also, the Chilean research group suggested that depression has a heterogeneous basis, requiring a different therapeutic plan for each patient. The severity of depressive symptomatology is influenced by the greater structural vulnerability of emotional self-regulation. ${ }^{13}$

Regarding the neurobiology of these cases, it was possible to observe that depressive patients in psychodynamic psychotherapy treatment normalized their brain activity, characterized by hyperactivity of the limbic system, after 8 months of treatment, without medication. This study used sentences from the OPD as a stimulus for the assessment of brain activity in the patients and control group. ${ }^{19}$

In psychiatric patients, Axis IV of the instrument showed good reliability; results demonstrated that patients with personality disorders have the most vulnerable mental functions. ${ }^{15}$ From the perspective of personality disorders in the DSM-IV classification, Dinger et al. investigated depressive patients, and part of the sample also had personality disorder when assessed with the OPD (Axis IV) and OPD-SQ. It is noteworthy that both the OPD-SQ and the OPD Levels of Structural Integration Axis (OPD-LSIA) were useful for assessing the personality functioning of depressed patients with or without Personality Disorders according to DSM-IV diagnostic criteria. ${ }^{14}$

Regarding personality disorders, in studies conducted prior to publication of the DSM-5, Zimmermann et al. pointed out a possibility for better evaluation of these patients. They integrated the OPD perspective into the understanding of personality from the OPD-LSIA. The overall OPD-LSIA score was associated with severity of personality disorder, showing it to be a reliable and valid measure for assessment of personality structure. ${ }^{20}$

The studies cited are German, $14,19,20$ where it can be observed that researchers are currently more focused on understanding the personality and subject structure. Concomitant with this, Germans have also conducted research on unconscious conflicts - Axis III -the understanding of which is identified as a fundamental factor in understanding of the genesis and maintenance of mental disorders, since they provoke behavioral, emotional and neural reactions. Each conflict comprises affections, thoughts, beliefs, behavior, relationship, and transference-countertransference characteristics, among others. ${ }^{17}$ In this sense, conflict was also used in an attempt to investigate repression; a central concept in psychodynamic theory. It proved possible to propose a way to assess repression using free association of sentences related to the intrapsychic conflict. ${ }^{18}$

It can be observed that these studies are developing each dimensional axis separately and in the most 
varied of contexts: neuroscience, OPD-SQ, and OPDLSIA. Additionally, in an attempt to correlate the OPD constructs with another instrument, the Americans Gordon and Stoffey chose the Psychodiagnostic Chart (PDC), a preliminary instrument developed to operationalize the Psychodynamic Diagnostic Manual (PDM). In their results, the PDC correlated significantly with the OPD-Axis IV. ${ }^{16}$

The OPD-2 was also used to assess adherence to treatment among epileptic patients. In this study, the authors found that adherence to treatment is influenced by aspects of experience of the disease - Axis I - and by conflict - Axis III - in epileptic patients. ${ }^{7}$ Chilean research, especially that involving the researcher Paula Dagnino, investigated the context of therapeutic focus and change. The authors pointed out that the focus on the OPD promoted therapeutic chang $\mathrm{e}^{12}$ and this change was progressive and irregular. ${ }^{11}$

In another Chilean context, the OPD was adapted to domestic violence, using Axis I. Here, the author evaluated the psychodynamic functioning of 28 women recruited from a center for domestic violence victims in Santiago. The women who demonstrated the greatest severity of violence were those who reported higher presence of depressive symptoms, PTSD, and low education. Complementarily, the main conflict that prevailed was need for care versus self-sufficiency $(39 \%)$, followed by the secondary conflict submission vs. control (50\%), which may be related to re-victimization. Also, the overall functioning of women who had been victims of sexual violence was worse than that of other victims, because they suffered from psychological and physical violence concurrently; with an accumulation of multiple traumas. Furthermore, the vulnerable structure due to the trauma suffered is considered an obstacle to victims dealing with their emotions and stress. ${ }^{6}$

Also in the context of violence, in Brazil the OPD-2 also proved useful with adolescents in conflict with the law, for identifying the psychodynamic characteristics of the case, complementing the diagnosis of Conduct Disorder. These authors developed an evaluative comprehension of the adolescent, pointing out that the predominant intrapsychic conflict was his need for care versus self-sufficiency active mode. He sought independence because of fragile primary affective bonds; which led him to perceive others as controllers and so he isolated himself or acted impulsively, perhaps as an attempt to avoid another possible abandonment. Nevertheless, the patient presented a median psychic structure, which did not lack mentalization ability. These aspects demonstrate the complexity of the psychodynamic diagnostic assessment that surpasses the common psychiatric diagnosis. ${ }^{8}$
In diagnosis of acute stress disorder (ASD) and posttraumatic stress disorder (PTSD) it was observed that patients presented peculiar characteristics due to urban violence. The three patients assessed in the study by Both et al. from the perspective of the OPD-2 exhibited moderate subjective distress, with emotional and social difficulties, modifying their relational behavior: hypervigilance, and care of others as support. The main conflict was around the need for care versus self-sufficiency in the active and passive mode. Thus, they certify the attention and care they receive or give submissive or self-sufficient - with a desire for care and security or as a defense against them. Both participants demonstrated difficulty with mentalization and trying to remain stable by avoiding affection; nevertheless, there was emotional inflexibility. General assessment of patients using the OPD enriched the understanding of patients, facilitating comprehension of the clinical context of stress. ${ }^{9}$

Only one study of eating disorders was found. These authors explored the psychodynamic diagnosis of 50 young women with eating disorders. The patients tended to perceive others as reproachful, controlling, belittling and neglectful. The predominant conflict was the need for care versus self-sufficiency. Most of the sample showed poorly integrated functioning. They pointed out that there is a need to consider the peculiarities of each patient, in addition to the nosological diagnosis. ${ }^{21}$

In several studies reviewed, when conflicts were evaluated with the OPD, the conflict need for care versus self sufficiency was the most frequent. This was observed in patients with eating disorder, ${ }^{21}$ acute stress disorder and posttraumatic stress disorder, ${ }^{6,9}$ and conduct disorder. ${ }^{8}$ These data raise the hypothesis that there are common characteristics among different pathologies that need to be better investigated, including through use of OPD in different contexts.

Finally, another Brazilian study from the Universidade Federal do Rio Grande do Sul (UFRGS) complemented the Portuguese sample and presented the Brazilian version of the instrument. ${ }^{2}$ The validation study found agreement between judges. In this validation study for Portugal/Brazil, reliability was calculated for each axis as follows: $78 \%$ in axis IV, $66 \%$ in axis I, $57.7 \%$ in axis III, and axis II was excluded. ${ }^{3}$ We questioned the exclusion of axis II, but it is understood that the 32 categories make reliability difficult to achieve. Nevertheless, the instrument was validated for use in Brazil.

It was observed that empirical production is increasing, since this is a recent instrument and it is increasingly spreading internationally. Chile and Germany are leading research on the subject. In Germany this is possibly because the group that created 
this instrument is from Germany and because it is already more widespread in their scientific community. Next is Brazil, where production is concentrated on understanding psychodynamic functioning in situations of stress, besides proposing its applicability to psychoanalysis notes.

Another aspect that is notable is related to academic courses. For example, in Latin America, there is only an academic course in Santiago, Chile; which limits expansion of the pool of professionals who have access to and permission to use the OPD as a clinical and research tool. Chile was the first country in America to introduce the OPD-2. Chilean studies of note prior to this review include one by Pérez et al., in which they advanced understanding of the OPD and achieved excellent agreement among judges, ${ }^{22}$ and Chilean researchers are also a reference in studies with depressive patients and, more recently, with women who have been victims of domestic violence. ${ }^{6}$ In Uruguay, Bernardi has made a relevant contribution in the area, with research that compares the personality diagnosis systems in the PDM, DSM, and OPD. ${ }^{23}$ In Argentina, relevant contributions to diagnosis of GADs have been made by Roussos. ${ }^{4}$

Dimensional diagnosis in addition to descriptive diagnosis is a clinical necessity that facilitates both understanding of the subject and clinical planning, offering an assessment of the internal dynamics and the meaning of the symptomatology exhibited. Therefore, the OPD is an instrument that integrates psychodynamic constructs in an operationalized manner using multiaxial assessment forms. This operationalization provides understanding of and application to the psychodynamics of the patient, offering greater clarity in planning of treatment for the subject and also facilitating communication within the scientific community. ${ }^{1}$ There are few instruments that operationalize the psychodynamic constructs, whether internationally or domestically. ${ }^{2}$ Therefore, we emphasize the need for research using the OPD instrument in the most varied of contexts, since the results can serve as tools for diagnostic investigation, contributing to improvement of psychotherapy and to understanding patients' dynamic functioning.

\section{Conclusion}

Analyses of studies related to the OPD showed that the number of publications on the subject is not yet significant and the methods employed are diverse, but there is a growing body of data on topics such as applicability in different contexts and to different pathologies, promoting greater visibility and with greater representativeness of professionals who understand the instrument We emphasize the importance of investing in research on the subject and of setting up academic courses in different countries in order to promote greater visibility and development of knowledge in this area. There is a scientific effort in the development of assessment and interventional processes using psychodynamic constructs, under a multiaxial diagnosis, whose priority is to create empirical evidence of the use of OPD in different contexts, with different pathologies, and with adaptations and comparisons to various other techniques.

The OPD- 2 is being used in several different countries and cultures, such as Germany, England, Italy, Chile, Australia, Portugal, and Brazil, not all of which are represented in the studies selected for this review, and in different clinical contexts. The instrument provides a deeper understanding of the patient in terms of identification of the patient's psychic suffering (axis I), dysfunctional relational patterns (axis II), predominant motivational conflict (axis III) and structural conditions (axis IV), which is complementary to the description of the patient's symptoms. With regards to treatment, it is possible to determine the most appropriate treatment indication for the subject and to carry out treatment planning and define the focus of treatment. Finally, it also contributes to scientific research and communication, since it presents psychodynamic aspects codified in clear and specific worksheets, as well being useful for training future therapists.

\section{Acknowledgements}

This study was financed in part by Coordenação de Aperfeiçoamento de Pessoal de Nível Superior (CAPES; finance code 001).

\section{Disclosure}

No conflicts of interest declared concerning the publication of this article.

\section{References}

1. Grupo de Trabajo OPD. Diagnóstico Psicodinámico Operacionalizado (OPD-2): manual para el diagnóstico, indicación y planificación de la psicoterapia. Barcelona: Herder; 2008.

2. Krieger DV. Operationalized Psychodynamic Diagnosis 2: apresentação da versão brasileira e estudos preliminares de validade e confiabilidade [dissertação]. Porto Alegre: Universidade Federal do Rio Grande do Sul; 2013.

3. Vicente CS, Oliveira RA, Silva F, Ferrajão P, Augusto S, Oliveira $\mathrm{S}$, et al. Cross-cultural adaptation of the operationalized 
psychodynamic diagnosis (OPD-2) in Portugal. Trends Psychiatry Psychother. 2012;34:129-38.

4. Juan S, Pescio N, Gómez Penedo JM, Roussos A. La conceptualización de un caso de trastorno de ansiedad generalizada (TAG) propuesta por terapeutas psicanalíticos. Análisis mediante los criterios del Diagnóstico Psicodinámico Operacionalizado 2 (OPD-2): resultados preliminares. Faculdad de Psicología - UBA, Secretaria de Investigaciones. Anu Investig. 2013;20:65-74.

5. Paulo AMR, Pires AP. Operacionalização psicodinâmica de diagnóstico (OPD-2) numa psicanálise. Psicol Clin. 2013;25:16378.

6. Crempien C. Psychological and relational functioning in Chilean women victims of domestic violence, with different levels of childhood relational adversity [thesis]. Heidelberg/Santiago: Faculty of Behavioural and Cultural Studies, Heidelberg University/ Pontificia Universidad Católica de Chile; 2012.

7. Alvarado L. Adherence to treatment in epilepsy. An assessment of subjective representations of Illness and psychodynamic conflicts [thesis]. Heidelberg: Institut für Psychosomatische Kooperationsforschung und Familientherapie der Universität Heidelberg; 2015.

8. Both LM Favaretto TC Benetti SPC Operationalized Psychodynamic Diagnosis (OPD-2) of an adolescent in conflict with the law. J Psychol Res. 2017;9:471-80.

9. Both LM, Malgarim BG, Freitas LH. Avaliação psicodinâmica de pacientes com Transtorno de Estresse Agudo e Pós-Traumático em uma instituição pública. "In press".

10. Crempien C, Grez M, Valdés C, López MJ, de la Parra G, Krause $M$. Role of Personality functioning in the quality of life of patients with depression. J Nerv Ment Dis. 2017;205:705-13.

11. Dagnino P, De la Parra G, Jaramillo A, Crempien C, Padilla $O$, Gómez-Barris E, et al. El devenir del cambio: Cómo es y hacia dónde se dirige. Rev Arg Clin Psicol. 2014;23:23-40.

12. Dagnino P. Focus in psychotherapy: characteristics and trajectories through the therapeutic process [thesis]. Heidelberg/ Santiago: Faculty of Behavioural and Cultural Studies, Heidelberg University/Pontificia Universidad Católica de Chile; 2015.

13. Dagnino P, Gómez-Barris E, Gallardo AM, Valdes C, De la Parra G. Dimensiones de la experiencia depresiva y funcionamiento estructural: ¿qué hay en la base de la heterogeneidad de la depresión? Rev Arg Clin Psicol. 2017;26:83-94.

14. Dinger $U$, Schauenburg $H$, Hörz-Sagstetter $S$, Rentrop M, KomoLang $M$, Klinkerfuß $M$, et al. Self-report and observer ratings of personality functioning: a study of the OPD system. J Person Assess. 2014;96:220-5.

15. Doering $S$, Burgmer $M$, Heuft G, Menke D, Bäumer B, Lübking $M$, et al. Assessment of personality functioning: validity of the Operationalized Psychodynamic Diagnosis Axis IV (Structure). Psychopathology. 2014;47:185-93.

16. Gordon R, Stoffey R. Operationalizing the psychodynamic diagnostic manual: a preliminary study of the psychodiagnostic chart. Bull Menninger Clin. 2014;78:1-15.

17. Kehyayan A, Best K, Axmacher N, Kessler H. Neural activity during association to conflict-related sentences. Front Hum Neur. 2013;7:705.

18. Kessler $H$, Schmidt AC, Hildenbrand O, Scharf D, Kehyayan A, Axmacher N. Investigating behavioral and psychophysiological reactions to conflict-related and individualized stimuli as potential correlates of repression. Front Psychol. 2017;8:1511.

19. Wiswede D, Taubner S, Buchheim A, Münte T, Stasch M, Cierpka M, et al. Tracking functional brain changes in patients with depression under psychodynamic psychotherapy using individualized stimuli. PLoS One. 2014;9:e109037.

20. Zimmermann J, Ehrenthal JC, Cierpka M, Schauenburg H, Doering $\mathrm{S}$, Benecke $\mathrm{C}$. Assessing the level of structural integration using operationalized psychodynamic diagnosis (OPD): implications for DSM-5. J Person Assess. 2012;94:522-32.

21. Zuccarino ML, Zuglian P, Magni M, Rosseti A, Manna G, Gentile $M G$, et al. Eating disorder subtypes in a young female sample using the operationalized psychodynamic diagnosis system: preliminary results. Adolesc Psychiatry. 2012;2:333-44.

22. Pérez $F$, Alvarado $L$, De la Parra G, Dagnino P. Diagnóstico Psicodinámico (OPD-2): evaluación preliminar de la validez y confiabilidad inter-evaluador. Rev Chil Neuro-Psiquiatr. 2009;47:271-8.

23. Bernardi R. DSM-5, OPD-2 y PDM: Convergencias y divergencias entre los nuevos sistemas diagnósticos psiquiátrico y psicoanalítico. Rev Psiquiatr Urug. 2010;74:179-205.

\section{Correspondence:}

Luciane Maria Both

Rua Ramiro Barcelos, 2350

90035-903 - Porto Alegre - Brazil

E-mail: lucianeboth@gmail.com 